\title{
Conservation and grazing in Australia's north-east: the bridled nailtail wallaby
}

Fiachra Kearney ${ }^{1 *}$, Ryan RJ McAllister ${ }^{2}$ and Neil D MacLeod ${ }^{2}$

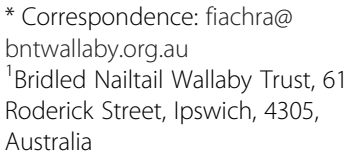

* Correspondence: fiachra@ bntwallaby.org.au

${ }^{1}$ Bridled Nailtail Wallaby Trust, 61 Roderick Street, Ipswich, 4305, Australia

\begin{abstract}
Australia's vast continent is dominated by semi-arid and arid landscapes that have been modified to support the development of an extensive livestock grazing industry. Historically, this development has come at great environmental cost, with wide-scale landscape degradation and loss of biodiversity, including small macropods. With the growing appreciation of environmental values and ecological services provided by grazing landscapes, the engagement of pastoral landholders is now central to contemporary conservation efforts. In this paper we explore the spluttering recovery of Australia's critically endangered bridled nailtail wallaby Onychogalea fraenata, once presumed extinct but now subject to a limited rehabilitation program in Queensland. We explore the 'fit' between management units and the scale of conservation challenges for the bridled nailtail wallaby, and then use this to frame the role of the private grazing industry in the governance of conservation actions. A centralised state conservation program has largely failed to stop the decline of the species, which remains critically endangered. We argue that non-state (privately) managed grazing properties working within a multi-level governance system that includes the state have a greater chance of conservation success because their actions can more appropriately match the scale of the problem at the implementation level. If the species recovers, the balance of management focus will need to shift towards broader scale actions such that localised disconnected sub-populations can successfully interbreed. By analysing the institutional failures that surround the bridled nailtail wallaby, we provide recommendations on how public institutions or policies can successfully catalyse private sector action at regional scales. These include avoiding economic incentives that may crowd out local stewardship, avoiding overly-authoritative state control (i.e. mono-centricity), and developing a multilevel governance structure that can strategically adapt its focus to the scale of various and shifting targets.
\end{abstract}

Keywords: Brigalow, Scale mismatch, Institutional fit, Cattle

\section{Background}

Attempts to protect global biodiversity are rife with examples of conservation failures for species for which sufficient scientific information actually exists to otherwise support successful conservation efforts (Millennium Ecosystem Assessment 2005). Economic pressure on landscape managers to maintain viable activities (especially food and fibre production to satisfy the needs of increasing human populations) and progressive land-use change are leading drivers of species' decline. Often though, these drivers are themselves symptoms of underlying institutional failures. Institutions are

\section{焦 Springer}

(c) 2012 Kearney et al.; licensee Springer. This is an Open Access article distributed under the terms of the Creative Commons Attribution License (http://creativecommons.org/licenses/by/2.0), which permits unrestricted use, distribution, and reproduction in any medium, provided the original work is properly cited. 
the social norms, and non-regulatory and regulatory rules that govern the actions that both drive conservation issues and prohibit conservation actions (see Young 2002). In this paper we explore the history of the conservation of the Endangered bridled nailtail wallaby (Onychogalea fraenata). This species' once wide-scale semi-arid range has been heavily disturbed by predation from feral pests (e.g. foxes and dingoes) and extensive land clearing for pasture development for livestock grazing to the point that it is threatened by extinction. The sheer scale of habitat loss and predation load is such that, like many threatened savanna and woodland floral and fauna species, the wallaby population cannot feasibly be recovered and then protected within the limited network of formal conservation reserves that exist in the extensive grazing regions of Australia (e.g. McIntyre and Barrett 1992; Pressey 1995; Young and Howard 1995). Given that the larger part of the landscape is now privately owned and managed by pastoralists, it is inevitable that the solution to securing the wallaby's future will have to be found on that grazing land and the pastoralist community will potentially be key players in any serious efforts to recover the species. However conservation efforts for the wallaby remain fragmented and poorly coordinated and the broader pastoralist community, which derives little apparent value from the species presence on their land, is largely disconnected from both the species and its protection.

International evidence suggests that where communities are excluded from the governance of their local resources conservation efforts will generally fail. For example, in Africa's Maasailand poor relationships between the state and individual enterprises have been disempowering local communities thus hampering both conservation and livelihood outcomes (Homewood and Thompson 2009). In South America, international involvement in the efforts to protect the vicuna have worked perversely to both endanger and protect the species, but a lack of community engagement in active recovery efforts is ultimately threatening its sustainability (Lichtenstein and Carmanchahi this edition; McAllister et al. 2009a). At the other extreme, however, others warn that simply seeking to empower local resource users provides no guarantee for achieving conservation success (Bradshaw 2003). Questions have been raised over the credibility of the sustainability agendas of local communities and their capacity to actually implement them (Nelson and Agrawal 2008), as well as the credibility of efforts of central authorities to truly devolve power to local resource users (Bradshaw 2003).

A framework for exploring conservation problems is emerging around the problems of 'institutional fit' (see Cumming et al. 2006; Folke et al. 1998). This framework is centred on the concept that management that is required to put scientific information to good use will necessarily operate at temporal and spatial scales that are frequently inappropriate for the problem at hand. More broadly, the outcome of collective management will largely be determined by the suite of policy and private actors who 'interplay' around particular conservation issues. This collective construct of management is referred to as multilevel governance. The key to managing the problem of establishing appropriate institutional fit lies not merely in fitting the management to a particular scale, but rather exploiting the multilevel aspect of governance systems in order to adaptively coordinate the various conservation activities. In this context, pastoralists working at a local scale need to be given authority to undertake local conservation decisions, but with connectivity and accountability established within a broader system of governance. 
Therefore, pastoralists holding the status of owners and managers of the greater proportion of local grazing landscapes need to be key partners in managing those landscapes for conservation outcomes. However, grazing per se is by no means the saviour of Australia's threatened biodiversity. The grazing industry working within the context of a long history of policy support has undertaken extensive land clearing and pasture development actions that have had a dramatic effect on landscape ecological values (McIntyre et al. 2002; Woinarski and Fisher 2003) and soil function (Kaur et al. 2007). High grazing intensity reduces cover and thereby increases sediment losses (Bartley et al. 2010); reduces total soil nitrogen and organic carbon (Beyer et al. 2011); interrupts natural fire cycles (e.g. Hodgkinson et al. 1984); and reduces the abundance of bird species (Martin et al. 2005) and small mammals (Woinarski and Fisher 2003).

Nevertheless, while substantial environmental degradation in Australia has been attributed to livestock grazing (NLWRA 2002; Tothill and Gillies 1993), the grazing industry is potentially a critical resource and a partner to national efforts to conserve biodiversity (Campbell 1995), and particularly some highly endangered species. There is no technical possibility of re-creating pre-European rangeland systems of Australia, nor would it be economically sensible to attempt to do so (Pannell 1999, 2000). These vast landscapes need to be actively managed to achieve either sustainable production or conservation outcomes, and policies of complete abandonment will offer limited benefit to any party. As such, working actively with the pastoral industry into the future is essentially the only realistic option open for improving biodiversity outcomes across large tracts of the landscape.

We focus on a northern Australian rangeland case-study, where a commerciallyoriented livestock grazing land-use system has largely replaced one of traditional Aboriginal resource use. Specifically we recount conservation efforts of the bridled nailtail wallaby. It is important to note that for bridled nailtail conservation there are limited tangible co-benefits with grazing. Hence the problem is one of co-existence, and of how to structure a governance system specifically targeted for a multi-scale conservation problems that incorporates action in grazing enterprises. We argue the existence and effect of institutional inadequacies using scale mis-matches as our analytical framework. A key focus of the review is on how and why conversation of the species on nonstate, privately managed grazing properties may have some success if managed appropriately and how state institutions might work to successfully upscale such non-state successes.

\section{History of the demise of the bridled nailtail wallaby}

The bridled nailtail wallaby is a small, solitary ash-grey macropod with striking markings across its shoulders resembling a white bridle, and a distinct black-stripe along its spine (Figure 1). Males and females weigh $5-8 \mathrm{~kg}$ and $4-6 \mathrm{~kg}$ respectively. Of the three species in the genus, the northern nailtail wallaby (O. unguifera) is presently secure in status (Ingleby 1991), the crescent nailtail wallaby (O. lunata) is 'Presumed Extinct' (Burbidge 1983) and the bridled nailtail wallaby is classified as being 'Endangered' (Evans and Gordon 2008).

The bridled nailtail wallaby was once distributed across millions of square kilometres ranging from Charters Towers in north Queensland down to the Murray River on the New South Wales-Victorian border. Habitat for the species varies through open grass 


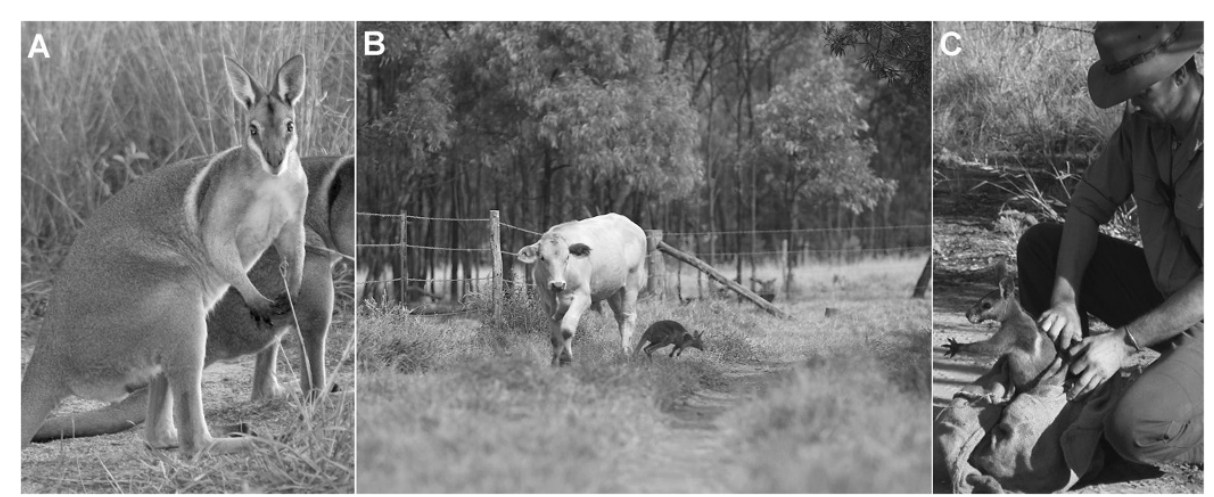

Figure 1 Bridled nailtail wallaby: (A) showing striped markings on back (๑ Project Kial), (B) with livestock on Avocet grazing enterprise ( $\odot$ Brian Siebel 2008) and, (C) monitoring (๑ Brian Siebel 2008).

woodlands (Eucalypt dominant) to dense shrublands (Acacia dominant), although it generally shows a marked preference for more fertile areas of the landscape and especially transition areas where dense shrubland and grassy woodlands meet (Evans and Gordon 2008; Gordon and Lawrie 1980). The animal appears to prefer to shelter in the thick shrubs and fallen timber by day and nocturnally graze shorter pastures, and when feeding in open pasture stays close to the edge of the thicker shelter habitat presumably to evade detection by predators (Evans and Gordon 2008; Tierney 1985).

Like many small-medium sized Australian mammals the populations of the bridled nailtail wallaby suffered precipitous declines following European colonisation and the expansion of pastoralism across the continent (Gordon 1983). In fact, there were no confirmed sightings of the wallaby between 1937 and 1973 and the animal was generally thought to have become extinct. There are many factors underlying the dramatic decline in wallaby numbers across its historic range, and these are thought to have been mutually reinforcing, such as significantly increased predation rates following the introduction of foxes and feral cats, extensive clearing of native vegetation (especially Acacia shrublands) for pasture development and the alteration of habitat structure and composition by further vegetation management and selective grazing by livestock where some of the original habitat remained (Lavery and Tierney 1985).

Grazing by sheep has been specifically implicated as a driver for the early phases of the decline in the wallaby's range because the animal relies heavily upon herbs and forbs for forage, with some selection of native grasses, and the species occupies a fairly narrow niche in the trophic system (Gordon and Lawrie 1980). Sheep grazing created direct competition for food and ultimately lead to a broad-scale compositional change within the shrubland and adjacent woodland understory. In the northern part of the wallaby's former range, beef cattle largely displaced sheep as the principal grazing animal and the competitive effect possibly came more through structural modification of the shrub understory through animal movement and trampling rather than direct competition for forage and consequent compositional change of the grass and forbs communities.

The major structural change in the northern habitat associated with expanding cattle numbers largely came through the wide scale clearing of the Acacia shrublands (especially Brigalow - Acacia harpophylla) and sowing of buffel grass (Cenchrus ciliaris) pastures under various publicly sponsored land development schemes from 
the early 1960's (QLAC 1968). Buffel grass typically alters the shrub understory structure and, if left unmanaged, can create dense physical barriers that extend over areas that are large enough to prevent the effective migration and immigration of smaller animals (Eyre et al. 2009; Smyth et al. 2009). This particular grass species can also outcompete native grasses and forbs, thereby decreasing food availability and selection for the bridled nailtail wallaby. Buffel grass can also support hotter fires than the maximum temperature that the acacia overstory can withstand, thus further removing suitable habitat for the wallabies (Miller et al. 2010).

A remnant population of the species was rediscovered on two grazing properties in Central Queensland in 1973 (Gordon and Lawrie 1980) in what is now Taunton National Park (Scientific) (see Figure 2E). This remnant population was immediately surveyed, the two properties on which it resided were acquired and a state (Queensland Government) conservation program was initiated by the National Parks Service. At the time of acquisition, the wallaby population was estimated at approximately 1400 individuals, with most of the animals located within the boundaries of Taunton National Park. From that time,

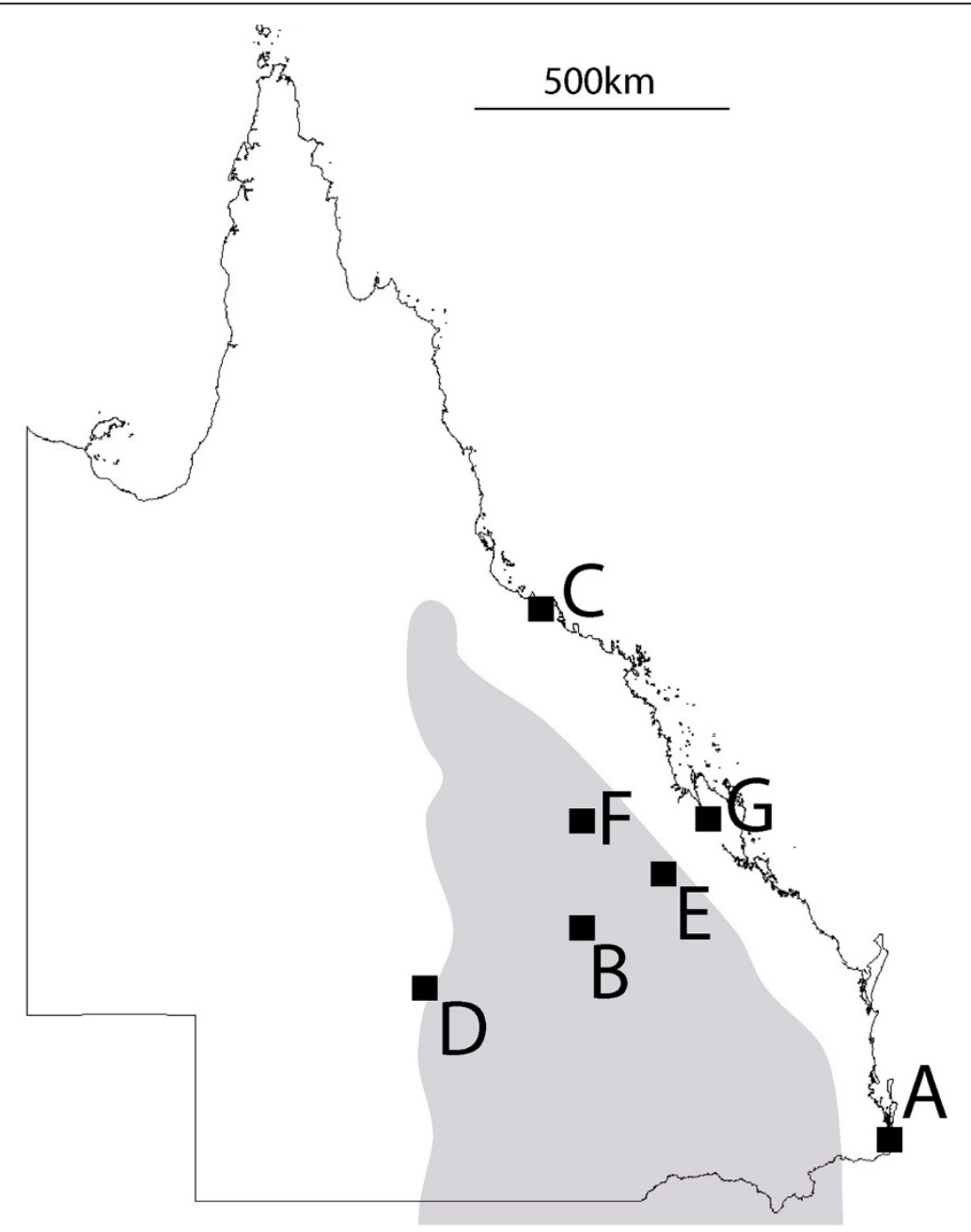

Figure 2 Key locations of bridled nailtail wallaby populations within Queensland: (A) Gold Coast; (B) Avocet Grazing; Property; (C) Townsville; (D) Idalia National Park; (E) Taunton National Park; (F) Gregory Mine; (G) private breeding facility. Shading indicates the approximate historical range. 
however, there appears to have been a substantial decline in wallaby numbers despite state plans to protect the species.

\section{Mis-matches in scale as an analytical framework}

The failure to conserve a species, and particularly to save it from extinction, can be seen simplistically as a failure in human behaviour. To positively influence species conservation efforts, human behaviours need to be understood in terms of the rules that govern them - social norms, and regulatory and non-regulatory rules that are applied by multiple scales of government. These rules are 'institutions' and can been categorised as either 'rules on papers' which refer to the literal interpretation of legislative rules about what actions can be enacted, or 'rules in use' which refer to how people will interpret the written rules and how they combine with social norms (Young 2002). Institutions also facilitate cooperation, and build future consequences into otherwise myopic decision making (Cumming et al. 2006).

Institutional settings have both spatial and temporal scales, and where conservation efforts do fail, it is often argued that the root cause of the failure lies in the scale of institutional settings not being aligned to the scale of the ecological processes that they purport to manage (e.g. Cumming et al. 2006; du Toit 2009; Folke et al. 1998). We briefly consider the concept of mis-matches in scales and summarise their implications, before using this framework to explore the history of conservation efforts for the bridled nailtail wallaby.

Scale relates to the extent over which processes bear influence. We refer to the ecological spatial scale as the geographical extent of fundamental ecological processes (see Cumming et al. 2006). The sociological spatial scale refers to the extent of the collective influence of "rules, polices and informal and formal culture norms", where this collectivization occurs through levels of social and jurisdictional organisation. Sociological spatial scales therefore also refer to the geographical extent of influence (e.g. state boundaries, neighbourhood). Cumming et al. (2006) note that, there are both empirical and subjective measures of scale. Because the sociological scales involve composites of many actors and many institutions (e.g. Lubell et al. 2010) drawing scalar boundaries is necessarily more subjective. In fact the formation of many institutions is actually in directly response to the need to match ecological and management scales (e.g. see McAllister et al. 2009b).

Temporal scales are equally important in a framework for considering mis-matches of scale, and tend to be even more subjective as they relate to the memory or persistence of particular actions. For example, temporal scales may be driven by diverse factors such as the longevity of political decisions or the length a particular species' breeding cycle.

The crux of the framework is that where the scale of the ecological processes is not aligned to the scale over which management is attempted, effective conservation management is unlikely to emerge and poor outcomes are most likely to prevail. Two particular mis-matches of scales are common when attempting to address conservation problems. The first mis-match of scale involves politically driven sociological time scales that are much shorter than the time commitment required to successfully fulfil a particular conservation action (Table 1). The second mis-match of scale concerns 
Table 1 Implications of scalar mis-matches, adapted from Cumming et al. (2006)

\begin{tabular}{|c|c|c|}
\hline Scalar mis-matches & & Implications \\
\hline \multicolumn{3}{|l|}{ Spatial scales } \\
\hline broad sociological & fine ecological & $\begin{array}{l}\text { Too many managers. Micromanager syndrome; } \\
\text { lack of local knowledge leads to poor adaptability }\end{array}$ \\
\hline fine sociological & broad ecological & $\begin{array}{l}\text { No solutions for global problems, inconsistency } \\
\text { and competition across regions }\end{array}$ \\
\hline \multicolumn{3}{|l|}{ Temporal scales } \\
\hline long sociological & short ecological & Response times to slow \\
\hline short sociological & long ecological & $\begin{array}{l}\text { Management decisions lack continuity and consistency, } \\
\text { and limited consideration for the future }\end{array}$ \\
\hline
\end{tabular}

ecological problems occurring at broad spatial scales that are addressed by management actions that are applied well below the required spatial scale (or configuration).

How these mis-matches of scales will actually play out in practice relates to the concept of governance. Within any conservation agenda, there inevitably exists multiple management actions occurring at various scales that are the responsibilities of multiple actors whom likewise operate at multiple scales. Governance can take many forms. For example, power can be vested entirely with a centralised authority (i.e. mono-centric) or be distributed between public and private actors operating across a range of scales (i.e. multi-level), and each approach has advantages and disadvantages (see Termeer et al. 2010). When applied to the context of addressing conservation problems, it is necessary to think about what governance arrangement may work best in the context of having a set of required conservation actions to produce desired outcomes. It is also necessary to consider what governance arrangements will facilitate the best level of coordination across those necessary actions. This coordinating role can also take various forms. Traditionally, under the mono-centric governance model the central authority typically undertakes all coordination activities. Under the multi-level governance model, the coordination role adaptively emerges through the interplay between various levels of governance and across various scales (see Cash et al. 2006; Lubell et al. 2010).

Our purpose here, however, is not to specifically interrogate various models of governance, but to use this as a framework to consider the potential role of pastoralists as local land management agents for mitigating problems of institutional fit within these broader governance systems.

\section{Mono-centric conservation of the bridled nailtail wallaby}

In Queensland, the focus of this case example, all native fauna and flora are the exclusive property of the state (i.e. owned on behalf of the public by the Government of Queensland), including the bridled nailtail wallaby on both public and privately owned land. A state-based conservation program has been operating for the wallaby in Queensland from the time that the remnant population was re-discovered in 1973, During that time a some ecological, biological and management research has been undertaken relating to the species (e.g. Davidson 1991; Ellis et al. 1992; EPA/QPWS 1998; Fisher 1998; Gordon and Lawrie 1980; Horsup and Evans 1992; Lundie-Jenkins and Lowry 2005). Many management recommendations have been developed for conservation of the bridled nailtail wallaby from this body of knowledge, and some have been implemented. For example, feral cats are recognised to be major predators of 
young wallabies and thought to be responsible for suppressing juvenile recruitment, and dingoes are held responsible for the majority of adult deaths (Lundie-Jenkins and Lowry 2005). Therefore, effective predator control is considered to be essential for conservation success of the species and has been a recurring recommendation although only limited resources have actually been made available by the state to carry it out.

A captive-breeding population of wallabies was established in 1991 at a state run facility in north Queensland. In 1992 and 1997, two additional state controlled captivebreeding centres were established on the Gold Coast and at Gregory Mine, and also a private zoo facility at Rockhampton (Figure 2). Some animals were also translocated from Taunton National Park with the aim of establishing two additional discrete populations, which is a standard security measure for highly endangered species. The translocation sites were located at Idalia National Park (commenced 1996) and 'Avocet' which is 5,500-ha privately owned and operated cattle grazing property located near Springsure in Central Queensland (commenced 2001) (MacLeod et al. 2010). Both translocation sites were considered to meet the necessary habitat requirements for the bridled nailtail wallaby and also offer good scope for the implementation of necessary management procedures. A captive-breeding facility was also established at the Idalia National Park site, albeit temporary in nature.

Substantial financial resources have been expended on the state recovery program for the bridled nailtail wallaby -AUD \$3.39 million between 2005 and 2009, equating to approximately US\$ 2.7 million in 2009 - (Lundie-Jenkins and Lowry 2005), including land acquisition, human and other resources, education and protected area management. In addition, the state has invested in research into the ecology, behaviour and conservation needs of the species. The stated operational goal of the responsible agency is "to significantly improve the conservation status of the bridled nailtail wallaby...." (4th edition of the recovery plan for the bridled nailtail wallaby, 2005-2009). There were 8 specific targets to be reached which include (1) to enhance or maintain existing free-range populations of bridled nailtail wallabies at Taunton and Idalia National Parks, and Avocet Nature Refuge and (2) to establish two or more additional populations of the species (>100 individuals) within Queensland. A significant share of the conservation resources were directed to Taunton National Park which holds the source population for all recovery efforts. The Taunton population is also the most critical genetically (Sigg 2006) because it contains the highest allelic diversity (Seddon 2008). Pople et al. (2001) considered the translocation of animals to Idalia to be a success because the population there was estimated to have increased from 133 founders to in excess of 400 individuals. However, all captive breeding programs are expensive requiring challenging and intensive management to maintain genetic diversity (Stockwell et al. 1996) and to ensure that the translocated populations are not overly compromised. Sigg (2006) has subsequently reported progressive genetic loss within the translocated population in Idalia relative to the source population at Taunton National Park.

The estimated Taunton wallaby population declined markedly between 1991and 1994, from approximately 1400 individuals to around 450 individuals (Pople et al. 2001), the rapid decline being blamed primarily on folder deficiencies relating to severe drought conditions that prevailed in the region (Clancy and Porter 1993). In 2008 the Taunton population was estimated to have declined further to only 75 individuals (SE 63-93, 95\%) (Taunton National Park, unpublished workshop report). The breeding facility at Gregory 
Mine was also closed due to nutritional degradation of the natural foods on-site during a prolonged drought (Lundie-Jenkins and Lowry 2005).

From the late 1990s the NGO, Australian Wildlife Conservancy, has conducted a bridled nailtail wallaby breeding program on a privately owned, managed and fully enclosed and predator free facility known as 'Scotia Sanctuary', in southwestern New South Wales. As of the end of 2011 the sanctuary is reported to be holding in excess of 1500+ individual animals (AWC 2011). While this particular captive-breeding effort appears to have been successful in terms of the numbers of individual animals produced, the resident population is yet to be exposed to natural predation levels and appears to be confronted with substantial genetic losses in many of the individual animals (Seddon 2008). A very limited number of these animals may be able to be utilised to augment other populations if the necessary state approval can be obtained, but the core of the wallaby conservation efforts and all remnant and wild translocated populations presently remain in Queensland.

In 2011 the bridled nailtail wallaby still remains on Queensland, Australian and international endangered species lists, no new populations have been established, and the existing populations appear to still be declining. It would seem fair to conclude at this stage that the present mono-centric conservation approach that has been adopted for the bridled nailtail wallaby has not been particularly successful. An alternative approach would seem to warrant further scrutiny.

\section{Multi-level conservation on privately managed grazing lands}

From 2001, the owners of the 5,500 ha grazing property 'Avocet' have worked with the Queensland Government (Parks and Wildlife Service) to establish a quasi-state managed population of bridled nailtail wallabies on a formal reserve of approximately 1,100 ha (see previous section). This action has involved considerable costs being borne by private individuals having continued to forgo the full use of the habitat reserve land which is potentially productive grazing land, and incurring ongoing land management costs associated with maintaining the reserve (e.g. fire breaks, fencing). Several non-state initiatives have also worked with Avocet. An organisation of independent and voluntary licensed shooters (Conservation and Wildlife Management Queensland) was established in order to counter feral animal predation on native endangered species. This utilises trained individual volunteer shooters using their own equipment to control feral cats, foxes and dogs on conservation reserves. A small publicly registered conservation trust dedicated to bridled nailtail wallaby conservation was also founded (Bridled Nailtail Wallaby Trust) to facilitate and apply research, coordinate conservation efforts of non-state actors, lobby the state and draw attention to the failings of conservation. Both organisations approached the owner of 'Avocet' to assist with the management of the species, and a multi-level conservation approach was subsequently formed to achieve that goal.

The 'Avocet' private grazing property is presently the only location in Queensland where appropriate species and habitat management practices can be actively applied by non-state actors without being subject to the significant constraints that are presently imposed on non-government organisations operating on state controlled land. The private land-NGO partnership offers much greater flexibility and the opportunity to act pro-actively in the species conservation. 'Avocet's owner/manager, with support from NGOs, has initiated a series of conservation management activities at a level of effort 
that has not been previously employed. 'Avocet' is surrounded by other grazing enterprises, and hence there is unrealised potential to engage with surrounding pastoralists to address coordination of management conservation. While we hypothesise below that this governance model has the greatest potential to lead to sustained conservation outcomes, success has not yet been achieved.

A research study conducted on 'Avocet' in 2008 found approximately 40 individual animals (Kingsley 2009), which was far lower than expected given the progressive release of 166 animals from 2001. The reason for the apparent lack of success of the translocation effort on 'Avocet' remains unclear because there have not been adequate post-release surveys conducted, but a range of biotic and abiotic factors are likely to have had an impact on the bridled nailtail wallaby population since translocation activities commenced. As a consequence, a major focus on 'Avocet' has been directed to developing institutional capacity and structure in a way that may promote an effective conservation outcome in the future - viz. effective population monitoring, application of research recommendations, immediate response to disease or fire emergencies, formal adaptive management actions that are actually implemented.

Local conservation actions on Australian privately managed grazing enterprises are critical, but from both a pragmatic or a legal perspective they alone is unlikely conserve the bridled nailtail wallaby, even with support from NGOs. The NGOs that may partner private grazing enterprises are small and have a limited private support base, and also operate in a congested space in terms of public support for conservation initiatives (e.g. Greening Australia, Bush Heritage, Koala Foundation appeals etc.). Funding is typically a constant challenge for conservation projects that are focussed on relatively little-known species (Seddon et al. 2005). Hence for aspects of threatened species management that are costly and require highly specialised skills, such as genetic diversity management, the role of state is also critical. However, arranging and then managing state-NGO partnerships can be challenging. Public lobbying on behalf of either the species or its supporting NGO can create tension, and no formal mechanisms exist to cooperate on conservation efforts. Nonetheless, as private grazing land offers considerable potential to facilitate the implementation of effective conservation programs it is well worth proceeding with or without state cooperation insofar as this is possible.

\section{Potential win-wins}

While generally we consider that conservation of the bridled nailtail wallaby can coexistence with grazing, buffel grass management provides at least one example where pastoralist management can assist in meeting both conservation and grazing goals. Buffel grass is a widely planted pasture species throughout the grazing lands of central and western Queensland, is highly invasive, and is considered a major pest species by many conservation bodies (Miller et al. 2010). However, it is also an important fodder species for beef cattle production (Humphries 1967). Now found across vast tracts of northern and central Australia, its control on conservation lands is highly problematic, and it has been implicated in the ongoing decline of the bridled nailtail wallaby population on Taunton National Park (Taunton National Park, unpublished workshop report). 
Cattle grazing, especially using intensive periodic short duration grazing cycles, is accepted as an important management tool for controlling buffel grass (Butler and Fairfax 2008). While further buffel introductions may severely hinder conservation efforts, cattle grazing is an important management tool where this and other introduced grass species already exist, and working with pastoralists sympathetic to conservation goals on their property is imperative.

\section{Conservation ethos}

While profit is the underpinning motivator of many pastoralists' behaviour (Richards et al. 2005), evidence suggests that most pastoralists also have a strong environmental stewardship ethic (e.g. Green and MacLeod 2002; Greiner and Gregg 2011). This ethos needs support to achieve the required conservation goals. Yet there is potential for overly centralised policy to smother this stewardship by disempowering and ultimately de-motivating local stakeholders, and inducing complacency from local pastoralists concerning species conservation efforts on their holdings. Furthermore, insights from the emerging discipline of experimental economics suggest that attempting to monetarise altruistic behaviours, such as environmental stewardship, risks crowding out such actions (see Reeson and Tisdell 2008). This points to some value in the devolution of decision-making power to local stakeholders where this can encourage pastoralists existing stewardship motivations.

\section{Discussion}

\section{Governing from the bottom-up}

Our framework for understanding conservation failures for the endangered bridled nailtail wallaby has focussed on an examination of institutional failures in the dominant paradigm as well as advancing alternatives that offer greater potential success. A critical question that has been raised is whether or not bridled nailtail wallaby conservation management issues and resultant actions are necessarily being targeted at a scale that is appropriate to effectively address the problem. We are particularly interested in the potential role of pastoralists in effective landscape resource conservation, including local protection of endangered species, and so the framework seeks to understand their role within the broader system of governance. It is important to note, however, that such an institutional framework does not assume that there is a single panacea to solve all conservation problems. Regardless of the purpose, institutions are rarely, if ever, perfect.

Institutions that are created to address a specific purpose are not merely the product of a single issue. Institutions necessarily respond to geo-political contexts, ecological

Table 2 Major conservation sub-tasks and associated scales

\begin{tabular}{|c|c|c|c|}
\hline Sub tasks & Spatial scale required & $\begin{array}{l}\text { Temporal scale } \\
\text { required }\end{array}$ & Locations \\
\hline 1. Captive breeding & $<1$ ha & Years & \\
\hline 2. Isolated natural habit populations & 400-600 ha & Decades & $\begin{array}{l}\text { 'Avocet' - operational } \\
\text { grazing property }\end{array}$ \\
\hline 3. Genetic interplay between populations & $\begin{array}{l}\text { Connections between the } \\
\text { system parts }\end{array}$ & Decades & Queensland \\
\hline 4. Connected natural habit populations & $>500,000$ ha & Centuries & Nowhere - unlikely \\
\hline
\end{tabular}


and economic drivers, path dependencies and also to forces from other competing and complementary institutions. Complexity can foster resilience, but not perfection. Furthermore, conservation issues and drivers change continually, so a perfect institutional solution will only be "perfect" for particular moments in time and space. Therefore, in the absence of finding permanently perfect institutions to resolve complex conservation problems, a strong case exists for consciously building adaptive capacity into the governance of such problems.

Single conservation issues generally involve a range of management problems that individually operate across many scales (Table 2). For the bridled nailtail wallaby, captive breeding and on-property landscape restoration can maintain localised and isolated sub-populations, which is spatially a small-scaled problem. However, to truly recover the species across a significant range is a larger-scale problem that requires genetic interplay between the recovering sub-populations. Prior to European settlement, this genetic interaction was naturally maintained through species mobility across an unfragmented landscape. This is no longer possible, of course, and now requires conscious and intensive management.

Under a mono-centric governance model, species management may involve large sociological scales, yet is typically driven by political agendas drawn on relatively short temporal scales. Effective conservation management is necessarily built around much longer time horizons. In the specific case of conservation needs of the bridled nailtail wallaby, institutional coordination could realistically be centred around the state action plan for the species, with each actor/institution agreeing on clear responsibility for certain achievements. However, our governance-based framework would suggest that a lack management continuity and consistency, and limited consideration for the future are likely to be encountered as major problems (Table 1). Across the entire conservation agenda, some spatial mis-matches seem probable given various actions have differing requirements in terms to the scale of management (Table 2).

There is a clear need for broad sociological scaled management that can efficiently coordinate the genetic interplay across sub-populations, including those located on disparate privately owned and managed grazing properties and in captive breeding sites. Yet, if a broad sociological scaled institution were to manage all aspects of bridled nailtail wallaby conservation, it will likely be too broad to promote effective local action based on adaptive management principles - local conservation actions would likely be ineffectively micro-managed from above and based on decisions that lack local knowledge and the ability to take short-term actions as dictated by evolving local circumstances. In sum, such management lack adaptability (Table 1) and are unlikely to be effective. A mono-centric form of conservation governance is troubling in this context because even where conservation actions are locally driven, the centralisation of power can effectively scale all actions to that of the state-based, broad sociological scaled management.

This can be clearly illustrated by cases in which local scale conservation actions are having some success. 'Avocet' demonstrates how conservation efforts on privately owned and managed grazing properties can work at the implementation level because at that scale the local managers have relatively more decision-making autonomy than is the case for taking local actions on state managed land, and has external support to which the landholder also has direct input. Private landholder-NGO partnerships can 
help to support conservation efforts because they operate at the scale where direct action is required. Importantly, operation at local scales requires more than simply local managers having local issues as their focus. Private landholder-NGO partnerships potentially have the ability to make decisions at local scales because they operate in a decision-making environment that is relatively free from the inertia of bureaucracy. Such arrangements, therefore, have a capacity to make and apply sound decisions in a timely manner, and the absorption of land management costs by the participating pastoralists is part of their daily business. The private land-NGO partnership basically offers considerably more flexibility and the opportunity to act proactively.

The challenge then is how to get the best of both worlds? That is, how do you allow localised conservation to remain unhindered by slower broader scale management, while at the same time coordinating local scale management activities in order to ensure that the ecological function of a dispersed population can be re-created.

In this instance, by analysing the institutional failures, and showing how the private sector can be an effective conservator, we provide recommendations on how public institutions or policies can catalyse private sector action at appropriate regional scales. The case of the bridled nailtail wallaby provides a few clear messages for species conservation that may be generalised.

Strong centralised state control is unlikely to be the answer for effective conservation management because this potentially breaks the necessary match of scales between local land management action and localised conservation needs and outcomes. Rather, the broad aim for effective governance should establish structures that will foster local conservation management action and autonomy, and to place local actors within a broader multi-level governance system still requires accountability (but not necessarily in a hierarchical sense).

Economic incentives are an important consideration in terms of creating local action by pastoralists, especially where desirable conservation outcomes carry significant elements of the provision of public goods (Willis 1997), but caution is needed in designing such reward systems. Pastoralists already have a strong stewardship ethic (Greiner and Gregg 2011) and this class of stakeholders is not disinterested in environmental outcomes that flow from their decision making actions that are largely centred on production issues (e.g. Green and MacLeod 2002). Economic incentives, while appropriate to addressing externalities involving under-provision of environmental services such as biodiversity conservation (Pannell 2008), need to be careful not to crowd out pastoralists' intrinsic conservation ethics (Greiner and Gregg 2011) and altruistic behaviours (see Reeson and Tisdell 2008). Hence rather than focusing excessively on the need to create payments for conservation, the aim should be on harnessing increased commitment of pastoralists to undertaking additional conservation efforts by mitigating the costs of doing so, and to formally acknowledge their already significant contribution to land resource stewardship (Curtis and Delacey 1998).

The most challenging issue for implanting this model of governance is related to organising the broad sociological management, particularly in terms of coordinating the roles and actions of the prospective partners. If we accept the argument that a mono-centric governance model is unlikely to promote effective conservation actions for endangered species such as the bridled nailtail wallaby, then some form of decentralised coordination is required to ensure that the dynamic 
interactions between multiple actors across multiple forums does lead to good conservation outcomes.

Policy decisions and plans do not always have their intended impact, nor should they realistically be expected to. The reason is that 'impact' is rarely a function of a single policy, but instead is determined by a system of multiple, overlapping institutions. The interplay between the multiple institutions is largely determined by the ways in which various policy actors choose to engage with each other and the target issues across these multiple institutions. Further, the motivation for policy actors to engage in particular institutions is commonly one of self interest (Lubell et al. 2010). With no unifying master plan, while an emergent coordinated approach to policy can be managed, it cannot be strictly controlled.

Regardless of the context, the influence of an individual actor is largely determined by the extent to which their participation in a given issue modifies the dynamic actorinstitutional networks that emerge around such settings. The structure of these policy networks, that support bridled nailtail wallaby conservation, need greater attention. There is no single correct solution to this issue, and policy networks can range from top-down to bottom-up and designed or self-organized (see Hahn 2011). The important consideration for effectiveness is that networks that are established combine the requirements of accountability, and legitimacy of various responsibilities.

\section{Conclusions}

Given the large scales over which the landscapes of the Australian continent have been modified to support an extensive grazing industry, in contrast to the limited scale of the public conservation reserve system, it is clear that the future effectiveness of resource and nature conservation efforts must necessarily lie with the application of environmental stewardship at the local scale. Successive Australian governments have sought to devolve natural resource management powers to local communities (e.g. Landcare), but many questions surround the legitimacy of devolution and whether it is just an alternate form of centralised intervention (Lane et al. 2009; Marshall 2009). Nevertheless, adequate devolution of responsibility and decision-making powers is essential if vulnerable species and habitats are to be adequately conserved. The state-based conservation program for the bridled nailtail wallaby has largely failed to date to increase the population size, distribution and genetic diversity of the species, despite some individual successes. An examination of the scales of management suggests that for conservation outcomes on privately managed grazing enterprises to be positive, a new modus operandi for conservation governance is urgently needed. This new model should be one that enables effective multi-level coordination of actors and actions and reduces the downside limits of state mono-centricity. Such modus operandi are taking shape. There is no strong evidence as yet that such governance is already leading to successful on ground conservation outcomes. Yet without new models the risk is strong that a wide community of otherwise potentially willing pastoralists will be de-motivated from undertaking serious conservation efforts on their holdings, the area of land under effective conservation management will ultimately be reduced, and personal 
accountability for failure will remain weak. As rangeland environmental values are increasingly recognised outside of the regions in which they are generated, increased accountability of local stewardship actions will be required. This needs to be balanced with a genuinely inclusive governance structure in which the various aspects of complex conservation problems can be managed concurrently at appropriate scales.

\section{Competing interests}

FK is a director of the non-profit Bridled Nailtail Wallaby Trust while RRJM was a director between 2007 and 2010.

\section{Authors' contributions}

FK, RRJM and NDM co-authored the manuscript with respective foci on landscape ecology, governance and institutions, and grazing enterprises. All authors read and approved the final version of the manuscript.

\section{Acknowledgements}

Many thanks to Hugo Spooner the owner of 'Avocet', the collective membership of Conservation and Wildlife Management (Qld) and the individuals within the Queensland State Government for their commitment to the conservation of the bridled nailtail wallaby. RRJM acknowledges feedback from participants of the ARC Centre of Excellence for Environmental Decisions Workshop 22-26 August. Thanks to Bruce Taylor and Angela Guerrero Gonzalez for helpful comments on the manuscript.

\section{Author details}

${ }^{1}$ Bridled Nailtail Wallaby Trust, 61 Roderick Street, Ipswich, 4305, Australia. ${ }^{2}$ CSIRO, Ecosystem Sciences, PO Box 2583, Brisbane, 4001, Australia.

Received: 18 October 2011 Accepted: 27 January 2012

Published: 28 September 2012

\section{References}

AWC. 2011. Scotia: new horizons for the Bridled Nailtail Wallaby. Australian Wildlife Conservancy. Wildlife Matters Summer 2011(12): 12-13.

Bartley, R., J.P. Corfield, B.N. Abbott, A.A. Hawdon, S.N. Wilkinson, and B. Nelson. 2010. Impacts of improved grazing land management on sediment yields, Part 1: Hills lope processes. Journal of Hydrology 389: 237-248. doi:10.1016/j. jhydrol.2010.05.002

Beyer, S., A. Kinnear, L.B. Hutley, K. McGuinness, and K. Gibb. 2011. Assessing the relationship between fire and grazing on soil characteristics and mite communities in a semi-arid savanna of northern Australia. Pedobiologia 54: 195200. doi:10.1016/j.pedobi.2011.03.002.

Bradshaw, B. 2003. Questioning the credibility and capacity of community-based resource management. Canadian Geographer-Geographe Canadien 47: 137-150.

Burbidge, A.A. 1983. Crescent Nailtail Wallaby Onychogalea lunata. In The Australian Museum Complete Book of Australian Mammals, 206th ed, ed. R. Strahan. Sydney: Angus and Robertson.

Butler, D.W., and R.J. Fairfax. 2008. Buffel Grass and fire in a Gidgee and Brigalow woodland: A case study from centra Queensland. Ecological Management and Restoration 4: 120-125.

Campbell, C.A. 1995. Landcare: Participative Australian approaches to inquiry and learning for sustainability. Journal of Soil and Water Conservation 50: 125-131.

Cash, D.W., W.N. Adger, F. Berkes, P. Garden, L. Lebel, P. Olsson, L. Pritchard, and O. Young. 2006. Scale and cross-scale dynamics: Governance and information in a multilevel world. Ecology and Society 11: 12.

Clancy, TF, and G Porter.1993. Bridled nailtail wallaby (Onychogalea fraenata) recovery plan progress report No. 1. EPA QPWS Conservation Strategy Branch. Unpublished report to ANPWS, June 1993.

Cumming, G.S., D.H.M. Cumming, and C.L. Redman. 2006. Scale mismatches in social-ecological systems: causes, consequences, and solutions. Ecology and Society 11: 14.

Curtis, A., and T. Delacey. 1998. Landcare, stewardship and sustainable agriculture in Australia. Environmental Values 7 : 59-78. doi:10.3197/096327198129341474

Davidson, C. 1991. Recovery plan for the bridled nailtail wallaby (Onychogalea fraenata). ANPWS Endangered Species Program: Unpublished report to ANPWS. December 1991.

du Toit, J.T. 2009. Addressing the mismatches between livestock production and wild life conservation across spatiotemporal scales and institutional levels. In Wild rangelands: conserving wildlife while maintaining livestock in semiarid, ed. J.T. du Toit, R. Koch, and J.C. Deutsch. John Wiley \& Sons: Chichester.

Ellis, B.A., P.J. Tierney, and T.J. Dawson. 1992. The diet of the bridled nailtail wallaby (Onychogalea fraenata): site and seasonal Influences and dietary overlap with the black-striped wallaby (Macropus dorsalis) and domestic cattle. Wildlife Research 19: 65-78.

EPA/QPWS. 1998. Taunton National Park (Scientific) (Brigalow Belt biogeographic region): management plan. Brisbane: Environmental Protection Agency.

Evans, M., and G. Gordon. 2008. Bridled Nailtail Wallaby. In The Mammals of Australia, 3 rd Editionth ed, ed. S. Van Dyck and R. Strahan. Sydney: New Holland.

Eyre, T.J., J. Wang, M.F. Venz, C. Chilcott, and G. Whish. 2009. Buffel grass in Queensland's semi-arid woodlands: response to local and landscape scale variables, and relationship with grass, forb and reptile species. Rangeland Journal 31: 293-305. doi:10.1071/rj08035. 
Fisher, D. 1998. Behavioural ecology and demography of the bridled nailtail wallaby, Onychogalea fraenata. Brisbane: University of Queensland PhD Thesis.

Folke, C., L. Pritchard, F. Berkes, J. Colding, and U. Svedin. 1998. The problem of fit between ecosystems and institutions. Bonn: International Human Dimensions Programme on Global Environmental Change (IHDP).

Gordon, G., and B.C. Lawrie. 1980. The rediscovery of the bridled nailtail wallaby Onychogalea fraenata, (Gould) (Marsupialia: Macropodidae), in Queensland. Australian Wildlife Research 7: 339-345.

Green, J.L., and N.D. MacLeod. 2002. Barriers and opportunities for adoption. In Managing and conserving grassy woodlands, ed. S. McIntyre, J.G. Mclvor, and K.M. Heard, 177-200. Melbourne: CSIRO Publishing.

Greiner, R., and D. Gregg. 2011. Farmers' intrinsic motivations, barriers to the adoption of conservation practices and effectiveness of policy instruments: Empirical evidence from northern Australia. Land Use Policy 28: 257-265. doi:10.1016/j.landusepol.2010.06.006.

Hahn, T. 2011. Self-organized governance networks for ecosystem management: who is accountable? Ecology and Society 16: 18

Hodgkinson, K.C., N. HG, G.E. Griffin, J.C. Noble, and M.D. Young. 1984. Management of vegetation with fire. In Management of Australia's Rangelands, ed. G.N. Harrington, A.D. Wilson, and M.D. Young. Melbourne: CSIRO Publishing.

Homewood, K. and M. Thompson. 2009. Social and economic challenges for conservation in east African rangelands: land use, livelihoods and wildlife change in maasailand. In Wild rangelands: conserving wildlife while maintaining livestock in semi-arid, ed. J.T. du Toit, R. Koch, and J.C. Deutsch. John Wiley \& Sons: Chichester.

Horsup, A., and M. Evans. 1992. Predation by Feral Cats, Felis catus, on an endangered marsupial, the bridled nailtail wallaby, Onychogalea fraenata. Australian Mammalogy 16: 85-86.

Humphries, L.R. 1967. Buffel grass (Cenchrus cilaris) in Australia. Tropical Grasslands 1: 123-124.

Ingleby, S. 1991. Distribution and status of the Northern Nailtail Wallaby, Onychogalea unguifera (Gould 1841). Wildlife Research 18: 655-676.

Kaur, K., R.K. Jalota, and D.J. Midmore. 2007. Impact of tree clearing on soil attributes for a pastoral property in central Queensland, Australia. Soil Science 172: 516-533. doi:10.1097/SS.0b013e31804fa286.

Kingsley, L. 2009. Evaluation of the Success of an Off-park Translocation of the Endangered Bridled Nailtail Wallaby, Onychogalea fraenata. Brisbane: University of Queensland MSc Thesis.

Lane, M.B., A. Haygreen, T.H. Morrision, and J. Woodlands. 2009. Will regionalisation achieve intergated natural resource management? In Contested Country, ed. M.B. Lane, C.J. Robinson, and B. Taylor, 59-74. Melbourne: CSIRO.

Lavery, H.J., and P.J. Tierney. 1985. Scarcity and Extinction. In The Kangaroo Keepers, ed. H.J. Lavery. Brisbane: University of Queensland Press.

Lichtenstein, G, and P Carmanchahi. this edition. Payún Matrú: an alternative model for guanaco sustainable use. Pastoralism this edition

Lubell, M., A.D. Henry, and M. McCoy. 2010. Collaborative Institutions in an Ecology of Games. American Journal of Political Science 54: 287-300. doi:10.1111/j.1540-5907.2010.00431.x.

Lundie-Jenkins, G., and J. Lowry. 2005. Recovery plan for the bridled nailtail wallaby (Onychogalea fraenata) 2005-2009. Report to the Department of Environment and Heritage (DEH). Brisbane: Environmental Protection Agency/ Queensland Parks and Wildlife Service.

MacLeod, N.D., F.C. Kearney, H. Spooner, and M. Woods. 2010. Conservation of critically endangered wildlife species - scope for private landholder and citizens' action. In 16th Biennial Conference Papers. Burke: Australian Rangeland Society.

Marshall, G.R. 2009. Can community-based NRM work at the scale of lagre regions? Exploring the roles of besting and subsidiarity. In Contested Country, ed. M.B. Lane, C.J. Robinson, and B. Taylor, 43-57. Melbourne: CSIRO.

Martin, T.G., P.M. Kuhnert, K. Mengersen, and H.P. Possingham. 2005. The power of expert opinion in ecological models using Bayesian methods: Impact of grazing on birds. Ecological Applications 15: 266-280. doi:10.1890/03-5400.

McAllister, R.R.J., D. McNeill, and I.J. Gordon. 2009a. Legalizing markets and the consequences for poaching of wildlife species: the vicuna as a case study. Journal of Environmental Management 90: 120-130. doi:10.1016/j. jenvman.2007.08.014.

McAllister, R.R.J., D.M. Stafford Smith, C.J. Stokes, and F. Walsh. 2009b. Patterns of accessing variable resources across time and space: desert plants, animals and people. Journal of Arid Environments 73: 338-346. doi:10.1016/j. jaridenv.2008.10.007.

McIntyre, S., and G.W. Barrett. 1992. Habitat variegation, an alternative to fragmentation. Conservation Biology 6: 146147. doi:10.1046/j.1523-1739.1992.610146.x.

Mclntyre, S., J.G. Mclvor, and K.M. Heard. 2002. Managing and conserving grassy woodlands. Melbourne: CSIRO Publishing.

Millennium Ecosystem Assessment. 2005. Ecosystem and human well-being. Washington DC: Island Press.

Miller, G., M. Friedel, P. Adam, and V. Chewings. 2010. Ecological impacts of buffel grass (Cenchrus ciliaris L.) invasion in Central Australia - Does field evidence support a fire invasion feedback? Rangeland Journal 32: 353-365. doi:10.1071/RJ09076

Nelson, F., and A. Agrawal. 2008. Patronage or participation? Community-based natural resource reform in sub-saharan Africa. Development and Change 39: 557-585. doi:10.1111/j.1467-7660.2008.00496.x.

NLWRA. 2002. Landscape health in Australia: A rapid assessment of the relative condition of Australia's bioregions and subregions. Canberra: Environment Australia and the National Land and Water Resources Audit

Pannell, D.J. 1999. Explaining non-adoption of practices to prevent salinity in Western Australia: Implications for policy. Nedlands: Agricultural and Resource Economics, University of Western Australia.

Pannell, D.J. 2000. Salinity policy: A tale of fallacies, misconceptions and hidden assumptions. Nedlands: Department of Agricultural and Resource Economics, University of Western Australia.

Pannell, D.J. 2008. Public benefits, private benefits, and policy intervention for land-use change for environmental benefits. Land Economics 84: 225-240. 
Pople, A.R., J. Lowry, G. Lundie-Jenkins, T.F. Clancy, H.I. McCallum, D. Sigg, D. Hoolihan, and S. Hamilton. 2001. Demography of bridled nailtail wallabies translocated to the edge of their former range from captive and wild stock. Biological Conservation 102: 285-299.

Pressey, B. 1995. Conservation reserves in NSW: Crown Jewels or leftovers? Search 26: 47-51.

QLAC. 1968. The brigalow story. Brisbane: Land Administration Commission, Department of Lands.

Reeson, A.F., and J.G. Tisdell. 2008. Institutions, motivations and public goods: An experimental test of motivational crowding. Journal of Economic Behavior \& Organization 68: 273-281. doi:10.1016/j.jebo.2008.04.002.

Richards, C., G.A. Lawrence, and N. Kelly. 2005. Beef production and the environment: Is it really 'hard to be green when you are in the red'? Rural Society Journal 15: 192-209.

Seddon, J. 2008. Genetic analysis of Bridled Nailtail Wallabies for Captive Breeding Programme. School of Veterinary Science, University of Queensland: Unpublished report.

Seddon, P.J., P.S. Soorae, and F. Launay. 2005. Taxonomic bias in reintroduction projects. Animal Conservation 8: 51-58. doi:10.1017/S1367943004001799.

Sigg, D.P. 2006. Reduced genetic diversity and significant genetic differentiation after translocation: Comparison of the remnant and translocated populations of bridled nailtail wallabies (Onychogalea fraenata). Conservation Genetics 7: 577-589. doi:10.1007/s10592-005-9096-3.

Smyth, A., M. Friedel, and C. O'Malley. 2009. The influence of buffel grass (Cenchrus ciliaris) on biodiversity in an arid Australian landscape. Rangeland Journal 31: 307-320. doi:10.1071/rj08026.

Stockwell, C.A., M. Mulvey, and G.L. Vinyard. 1996. Translocations and the preservation of allelic diversity. Conservation Biology 10: 1133-1141. doi:10.1046/j.1523-1739.1996.10041133.x.

Termeer, CJAM, A Dewulf, and M van Lieshout. 2010. Disentangling Scale Approaches in Governance Research: Comparing Monocentric, Multilevel, and Adaptive Governance. Ecology and Society 15

Tierney, P.J. 1985. Habitat and ecology of the bridled nailtail wallaby with implications for management. Brisbane: M. Sc. Thesis. Queensland Institute of Technology.

Tothill, J.C., and C. Gillies. 1993. The pasture lands of northern Australia. Brisbane: Tropical Grasslands Society of Australia. Occasional Publication No.5.

Willis, I.R. 1997. Economics and the environment. Sydney: Allen \& Unwin.

Woinarski, J.C.Z., and A. Fisher. 2003. Conservation and the maintenance of biodiversity in the rangelands. Rangeland Journal 25: 157-171. doi:10.1071/rj03013.

Young, O.R. 2002. The institutional dimensions of environmental change: Fit, interplay, and scale. Cambridge, MA: MIT Press.

Young, M.D., and B. Howard. 1995. Can Australia afford a representative reserve system by 2000? Search 27: 22-26.

doi:10.1186/2041-7136-2-20

Cite this article as: Kearney et al:: Conservation and grazing in Australia's north-east: the bridled nailtail wallaby

Pastoralism: Research, Policy and Practice 2012 2:20.

\section{Submit your manuscript to a SpringerOpen ${ }^{\circ}$} journal and benefit from:

- Convenient online submission

- Rigorous peer review

- Immediate publication on acceptance

- Open access: articles freely available online

- High visibility within the field

- Retaining the copyright to your article

Submit your next manuscript at $>$ springeropen.com 